\title{
A Research on Eurozone Bond Market and Determinants of Sovereign Bond Yields
}

\author{
Navjeet Gill \\ Nova School of Business and Economics, Lisbon, Portugal \\ Email:29370@novasbe.pt
}

How to cite this paper: Gill, N. (2018). A Research on Eurozone Bond Market and Determinants of Sovereign Bond Yields. Journal of Financial Risk Management, 7, 174-190.

https://doi.org/10.4236/jfrm.2018.72012

Received: May 17, 2018

Accepted: June 22, 2018

Published: June 25, 2018

Copyright $\odot 2018$ by author and Scientific Research Publishing Inc. This work is licensed under the Creative Commons Attribution International License (CC BY 4.0).

http://creativecommons.org/licenses/by/4.0/

(c) (i) Open Access

\begin{abstract}
This empirical research uses an OLS regression framework to examine the effect of the overall debt crisis on European sovereign bonds by conducting an overview of the bond market. It identifies the determinants which affect the generation of the indebtedness of sovereign bonds and play a major role in the determination of their solvency and hence, the spreads. These results reveal that Interest Rate, Inflation, Debt to GDP, Deficit to GDP, Gross Domestic Product rate of growth, and VSTOXX index are the most significant determinants of the sovereign bond spreads in the 6 sample countries, i.e. France, Germany, United Kingdom, Greece, Italy and Spain. To summarize, the main factors which affected bond spreads before the crisis, were not the country-specific fundamentals but rather the convergence of bond yields in the euro-zone countries due to and following the launch of the monetary union but during the crisis, increased risk aversion and lack of lender of last resort, shifted the focus to country specific factors and the bond spreads began to diverge according to the determinants highlighted in this study.
\end{abstract}

\section{Keywords}

Bond Markets, Financial Crisis, Interest Rates, Eurozone, Sovereign Spreads

\section{Introduction}

With due understanding, most states within the world seek lending from Eurozone markets in the form of Euro bonds, the low rate of interest on these bonds for servicing loans being one of the key reasons. In Europe, approximately two-thirds of the total outstanding securities are bonds, mainly sovereign bonds and bonds of financial intermediaries. Sovereign credit risk for developed countries was never a concern for investors before the 2007-2008 financial crisis. The rescue of local banks by their respective national governments could have been 
the trigger for the European sovereign debt crisis (Acharya et al., 2014). Large banks in the crisis hit countries had more than $100 \%$ exposure to own-country sovereign debt, hence directly affecting the sovereign credit risk (Blundell-Wignall, 2012). This caused an intra-euro area capital flight as investors moved their holdings of debt securities from stressed countries (e.g. Greece, Portugal, Italy and Spain) to non-stressed euro countries (mainly Germany) (Beck et al., 2016). This was the diffusion of the global financial crisis generated from America to other developed countries in Europe.

Euro central bank being a targeted bank tried to address the situation using a 2-pronged approach, firstly by covering the shortfall in market funding by further increasing the types of eligible collateral required to gain central bank funding, which helped avoid fire sales of assets by banks under stress. Secondly, in September 2012, ECB announced the conditional Outright Monetary Transactions, which removed the redenomination risk expressed in sovereign spreads (Praet, 2017).

The six countries in question about this crisis: Germany, Greece, Spain, Italy, France, and UK, are the fiscal policy giants in this region, also the rest of the world. That's why any force hitting the market would influence other market economies all throughout the rest of the world. There are several factors which influence/determine the yields of sovereign bonds in the global fiscal markets. The overall debt of the sovereign and other macroeconomic fundamentals have an impact on government bond yields such as government debt-to-GDP ratio, potential growth rate, real money market rates, inflation and primary balance ratio (Poghosyan, 2012). Before we narrow down to these factors, let's begin by looking at the overview of Euro area bonds market.

\section{Overview on the Eurozone Bond Market}

High debt growth rate in euro states had become a subject of concern across the globe. The sovereign debt crisis of the eurozone and its aftermath led to the establishment of the European Stability Mechanism (ESM) to provide financial assistance programs to the euro zone countries. Despite the first signs of recovery, the weight of debt remains a risk factor for many Euro-zone countries. The first major casualty of the debt crisis was Greece with its inability to settle its debt to banks in Euro-zone, financial institutions, and investment funds. It has ignited concerns about the risk of euro zone break-up and spread of the financial storm to other economies of the euro zone e.g. Italy, Spain, Ireland, and Portugal.

European countries led by France, Germany and IMF, are refinancing Greek debt in exchange for drastic fiscal austerity plan. Solutions to limit the spread of the financial crisis and reconstruct fiscal markets and credit facility rating agencies have been imagined by the states of the European region and European Central Bank, to host mechanisms of bringing the markets sovereign debt to more measured behaviors. The inability of some Euro-zone countries to meet their debt obligations to their creditors, is not the cause of the crisis, but is as a 
result of deep rooted fundamental problems such as the balance-sheet deficit and accumulated public debt over a period of decades. The crisis as we already know was exacerbated by the difficulty of obtaining funds in the financial market on favorable terms (interest rates, risk premium and insurance premium) as a result of investors' concerns especially in light of decisions taken by credit rating agencies to reclassify the public debt of the member countries in the region. The interest rates and insurance premiums associated with public debt with regard to this, must be raised and demanded by investors. Since the reduction of rating means to investors high risk of non-payment according to the return and risk base in the investment operations, the high risk leads to higher return on investment. Thus, financial markets and credit rating agencies are seen to have had a negative impact on the debt yields and exacerbated the crisis.

\subsection{The Causes of the Debt Crisis in the Euro Area}

The inability of some Euro-zone countries to meet insolvency control measures to their creditors has been discovered not to be the cause of crisis. Due to reasons rooted in the balance sheet deficit and accumulated public debt over a period of decades, it has been evolving from year to year. Also as a result of continued deficit in the balance sheets, the economic downturn that hit the developed economies in the wake of the comprehensive economic crisis (2007 and beyond), spread its effects to the rest of the world according to the degree of integration into the global economy of each country. Therefore, the main reasons for emergence of crisis in Euro-zone Organization can be identified as illustrated below.

\subsubsection{Structural Deficit in Balance Sheets}

Since the deficits in balance sheets of Euro-Mediterranean countries are rooted in the last decades of last century, Eurozone countries have been discovered to record an average budget deficit estimated at 0.4 percent of GDP in 1961-1973. From 1974-1984, and then moved to 5.9 percent in 1984-94. Thus, the average deficit for the period from 1973 to 1994 has been found to exceed 3 percent of the PIB which is agreed do not exceed the agreements for establishment of single currency. From 1995 to 2007, the balance sheet situation improved significantly due to favorable global economic conditions, low interest rates and adherence to the measures adopted in the framework of respecting agreed budget rules of the Eurozone countries. This reduced the deficit to below $3 \%$ (GDP) by 2.6 percent (GDP). However, due to adverse effects of the overall economic crisis (2007 and beyond), the deficit jumped to 5.2 percent of PIB in the post-crisis period from 2007 to 2010 for the Euro-zone countries combined. The situation can be illustrated by Table 1 .

It should be noted that the high rates of BIB deficit concern respectively Ireland, Greece, Portugal and Spain, with 31.3\%, 10.6\%, 8.9\% and 9.3\% respectively. These countries, suffer a twofold problem of public debts which are high and 
Table 1. Percentage of disability in balance sheets to the GDP for the EU 2010.

\begin{tabular}{cccccc}
\hline Countries & $\begin{array}{c}\text { Ratio of Disability } \\
\text { to GDP }\end{array}$ & Countries & $\begin{array}{c}\text { Ratio of Disability } \\
\text { to GDP }\end{array}$ & Countries & $\begin{array}{c}\text { Ratio of } \\
\text { Disability to GDP }\end{array}$ \\
\hline Austria & 4.4 & Latvia & 7 & Romania & 7.7 \\
Bulgaria & 3.5 & Luxembourg & 1.1 & Slovakia & 7.7 \\
Cyprus & 5.3 & Italy & 4.6 & Slovenia & 5.8 \\
Denmark & 2.6 & Belgium & 4.1 & Germany & 4.3 \\
Estonia & 0.2 & Spain & 9.3 & Sweden & 0.2 \\
Hungary & 4.2 & Malta & 3.6 & Finland & 2.5 \\
Lithuania & 8.3 & Holland & 5.1 & France & 7.1 \\
Bologna & 7.8 & Czech & 4.8 & Portugal & 9.8 \\
Greece & 10.6 & Ireland & 31.3 & & \\
\hline
\end{tabular}

Source: World Bank Open Data.

require a refund of premiums and services each year that can lead to a widening of deficit. It includes the large external debt with a long-term time horizon, on the other hand, the spread of the phenomenon of bribery and corruption that make incomes at low levels. Spain, Ireland and Portugal have been hit by the mortgage crisis with unexpected scenario before.

Greece has also experienced weak economic activity compared to economies of other euro area countries. Furthermore, figures on economic indicators provided to the bodies of European Union and the euro area, are false and exaggerated figures. The government reported a deficit of 6 per cent of GDP as regards the budget deficit for the first six years of 2010, while the real deficit remain estimated at 12.7 per cent during the same period.

On the basis of this misinformation, Standard \& Poor's reclassified Greek debt to $\mathrm{BB}+$, followed by the reclassification of Spanish and Portuguese debt. Line in line with the downgrade of the Greek debt rating, the Greek government began paying close to 11 percent in April 2010 as interest rate on loans demanded by the financial market in form of bonds or loans directly from banks. As a result, this situation has led to an increase in debt services and deepening of budget deficit.

\subsubsection{Excessive Public Debt and High Interest Rates}

Public debt is defined as the sum of financial pledges made under bank loans, government bonds, and treasury bills issued by the state, local communities, state public institutions, and social security agencies. A significant proportion of public debt is negotiable in the financial market. It is often the accumulation of the annual balance sheet deficit, as countries and their administrative bodies borrow to cover the budget deficit or fund future large-scale projects. The Maastricht agreement stipulated that the ratio of indebtedness to gross domestic product should not exceed 60 percent for each member of the euro area. However, most of the signatory countries did not respect this ratio, just as illustrated in Table 2. 
Table 2. Public debt compared to gross domestic product for the year 2010.

\begin{tabular}{cccc}
\hline Countries & $\begin{array}{c}\text { GDP } \\
\text { (billion euros) }\end{array}$ & $\begin{array}{c}\text { Public debt } \\
\text { (percent of GDP })\end{array}$ & $\begin{array}{c}\text { Public debt } \\
\text { (billion euros) }\end{array}$ \\
\hline France & 1931 & 28.3 & 1591 \\
Germany & 2477 & 83.2 & 2079 \\
Austria & 286 & 71.8 & 205 \\
Belgium & 354 & 96.2 & 341 \\
Cyprus & 17 & 61.5 & 11 \\
Spain & 1051 & 61 & 641 \\
Estonia & 14 & 6.7 & 1 \\
Finland & 180 & 48.3 & 87 \\
Greece & 227 & 144.9 & 329 \\
Ireland & 156 & 94.9 & 148 \\
Italy & 1556 & 118.4 & 1843 \\
Netherlands & 588 & 62.9 & 370 \\
Portugal & 173 & 93.3 & 161 \\
Slovakia & 66 & 41 & 27 \\
Slovenia & 35 & 38.8 & 14 \\
Bulgaria & 36 & 16.3 & 63 \\
Denmark & 236 & 43.7 & 1956 \\
Bologna & 354 & 45.9 & \\
Euro zone & 9176 & 85.4 & \\
& & & 193 \\
\hline
\end{tabular}

Source: World Bank Open Data.

Germany represents in terms of absolute value, the most indebted country in the euro zone, which reached a debt of 2079 billion euro. This makes it occupy the third most indebted economies in the world after United States and Japan, followed by Italy with a debt of 1843 billion euros and France with a debt of 1591 billion euros. Greece's debt is estimated at 340 billion euros. It's a country which is documented to not have complied with debt obligations, thus triggering Eurozone sovereign debt crisis. Greece's debt-to-GDP ratio is registered at $144.9 \%$, the highest level in the euro zone and the second highest in the world after Japan, followed by Italian debt which is rated at $118.4 \%$.

With regard to increased indebtedness in the euro area, the European Central Bank (ECB) lent to European banks during the period lasting 2007-2009, at very low interest rates to fight bankruptcy. A portion of the grant was meant to resolve local financial crisis in countries experiencing financial difficulties, especially Greece, that had registered a huge burden of debt.

After the panic and confusion caused by the financial market crisis, interest rates rose in line with rising risk premiums, increasing yield on government bonds, which encompassed interest rates, especially for fragile and vulnerable countries to the crisis (Greece, Portugal, Ireland). As a result, the high interest rate increased the leverage effect of debt services, which in turn increased the 
risk of repayment inability, leading to higher interest rates. The main determinant of solvency of the state is not only the size of its debt, but also the weight of the interest that must be paid within a specified period. A country whose debt is $100 \%$ of GDP, supposed to pay an interest rate of $3 \%$, should allocate $3 \%$ of GDP to servicing of the debt, without forgetting the rate of inflation.

Debt is a motor for developed countries to achieve economic growth. This is the current growth model in developed countries, particularly in the United States and Europe. The adoption of debt option for encouraging economic growth, led to a significant increase in external and internal public debts.

\subsubsection{The Negative Repercussions of Global Financial and Economic Crisis, Subject to Economic Contraction}

The financial and economic crisis started in 2007 in the United States of America. It became a global crisis and caused a blow to financial markets in many countries. It began with a sharp drop in real estate prices accompanied by a worsening of serious loans. As a result, financial institutions were placed at risk. They began to reduce interbank lending and impose high risk premiums on lending to individuals and institutions. The main result of the crisis was the restriction of lending to individuals and institutions by banks.

The crisis spread to the financial markets and financial institutions associated with these financial markets, which have suffered a significant loss of capital and a sharp decline in prices of their financial assets, which has led to the bankruptcy of many banks. Some banks are nationalized. US bank Lehman Brothers, the largest bank in the United States, declared bankruptcy in November 2008.

This is a situation which led to a crisis of confidence in financial sector, leading to disappearance of liquidity on financial markets. The financial crisis contributed to economic crisis with its transition to real economy, in terms; production and services sector, by reducing loans to banks, thus to higher financing costs to a slowdown economic growth and incomes. As a result, monetary authorities in United States and Europe supported banks by nearly $\$ 14$ trillion in 2007 and 2010 to maintain confidence in the banking system and prevent a collapse in the money supply. The same countries have also developed economic stimulus packages to stimulate economic growth and exit a recession.

The global financial and economic crisis has resulted in an unprecedented budget burden, characterized by reduced fiscal revenues (deflation), rising social burdens (unemployment), and additional burdens associated with measures to support economic activity and rescue the banking system. The direct cost of crisis associated with bank bailout costs (the state's share of bank debt and the purchase of doubtful assets) is estimated at 4.6 percent of GDP in Germany, 6.1 percent in the United Kingdom, and 3.5 percent in United States, and 5 percent in the European Union. These measures affected the balance sheets in Ireland, Denmark, Belgium, Netherlands, Austria and Germany. The cost of strengthening banking system in Ireland was more than 20 percent of GDP, resulting in a budget deficit of 32.4 percent of GDP in 2010 with public debt moving from 25 
percent of GDP in 2007 to 94.9 percent of GDP in 2010.

\subsubsection{The Role Played by Financial Markets and Credit Rating Agencies}

The debt crisis in the euro zone has been aggravated by excessive indebtedness by governments and its affiliates, with some governments unable to pay debt services in the sense of partial bankruptcy (Greece, Portugal, and Ireland). The crisis was exacerbated by the difficulty of obtaining funds in the financial market on favorable terms (interest rates, risk premium and insurance premium) as a result of investors' concerns especially in light of decisions taken by credit rating agencies to reclassify the public debt of member countries in the region. It's realized that interest rates and insurance premiums associated with public debt must be raised and demanded by investors. Since the reduction of rating means to investors the high risk of non-payment according to the return and risk base in investment operations, the high risk leads to higher return on investment. Thus, financial markets and credit rating agencies have played a vital role in the negative impact of the crisis.

Moody's, Fitch and Standard \& Poor's, are listed as the leading institutions in the world that hold $95 \%$ of the global business. They're known to evaluate the risk associated with a financial institution or product by assigning a rating based on the degree of risk assessed on economic and financial indicators. On this basis, the increased use of financial markets to cover the budget deficit has increased industrialized countries' dependence on financial markets and has therefore been assessed by the credit rating agencies.

Thus, financial markets and rating agencies played a negative role in the crisis through various mechanisms: interest rates, insurance premiums, risk premium, credit rating downgrade and expectations of potential investors. Financial markets and credit rating agencies are channels for spreading the crisis from one country to another due to the herd behavior of financial markets on the one hand, and the potential for support among the membership reduced. The risk of non-payment has increased, especially after the recent reclassification of the nine states.

\subsection{The Role Played by Eurozone Bond Market}

The dependence of countries in Euro area on financing their major projects and covering their budget deficits on financial markets by issuing short- and medium-term treasury bills and long-term state bonds, are subject to the moral influence of financial markets and seek economic decisions and measures to reassure financial markets. This implicit control of the financial markets is due to financing operations in European countries, to the European Union and the creation of the Euro Zone. Article 63 provides for freedom of movement of capital, not only between the States of the Union and the rest of the world. Article 123, paragraph 1, of the same Convention provides that the ECB shall not grant any form of lending to Member States or their public administrations. It also provides for the prevention of direct ECB acquisition of public debt securities of 
these countries (purchase from the primary market). Article 125, paragraph 1, also prohibits EU member states from lending to any State within the Union. Article 122, paragraph 2, also provides that the European Union is allowed to extend loans to a Member State only if faced with serious difficulties or threats such as natural disasters and special circumstances that evade any monitoring in order to finance the budget deficit. On this basis, only the recourse to financial markets was left to EU member States to obtain their financing needs. As a result of the worsening financial situation of the Eurozone member countries, the European Central Bank can intervene in the secondary market to buy state bonds provided that it is not rated $\mathrm{BBB}$, meaning, it is an investment bond. On this basis, the increased recourse to financial markets to cover the budget deficit has increased the dependency of the industrialized countries on financial markets. Hence they have been subject to valuation by credit rating agencies.

\section{Market Context: Divergence in Bond Yields}

The past four years have been characterized by unprecedented monetary easing by major central banks. To support economic activity, they lowered their key interest rate to almost $0 \%$. They have also put in place significant quantitative easing programs, primarily through the purchase of government bonds. They put downward pressure on bond rates around the world. The implementation of the ECB's program in March 2015 led to a significant drop in bond rates, not only in Europe but also in the rest of the world. The sharp drop in oil prices since mid-2014 has also put downward pressure on the rates.

Yield is one of the most important concepts in bond investing, being the instrument used to measure the yield between bonds. The yield on bond investment may change to reflect price movements in bonds arising from interest rate fluctuations. Figure 1 below shows yields on European bonds.

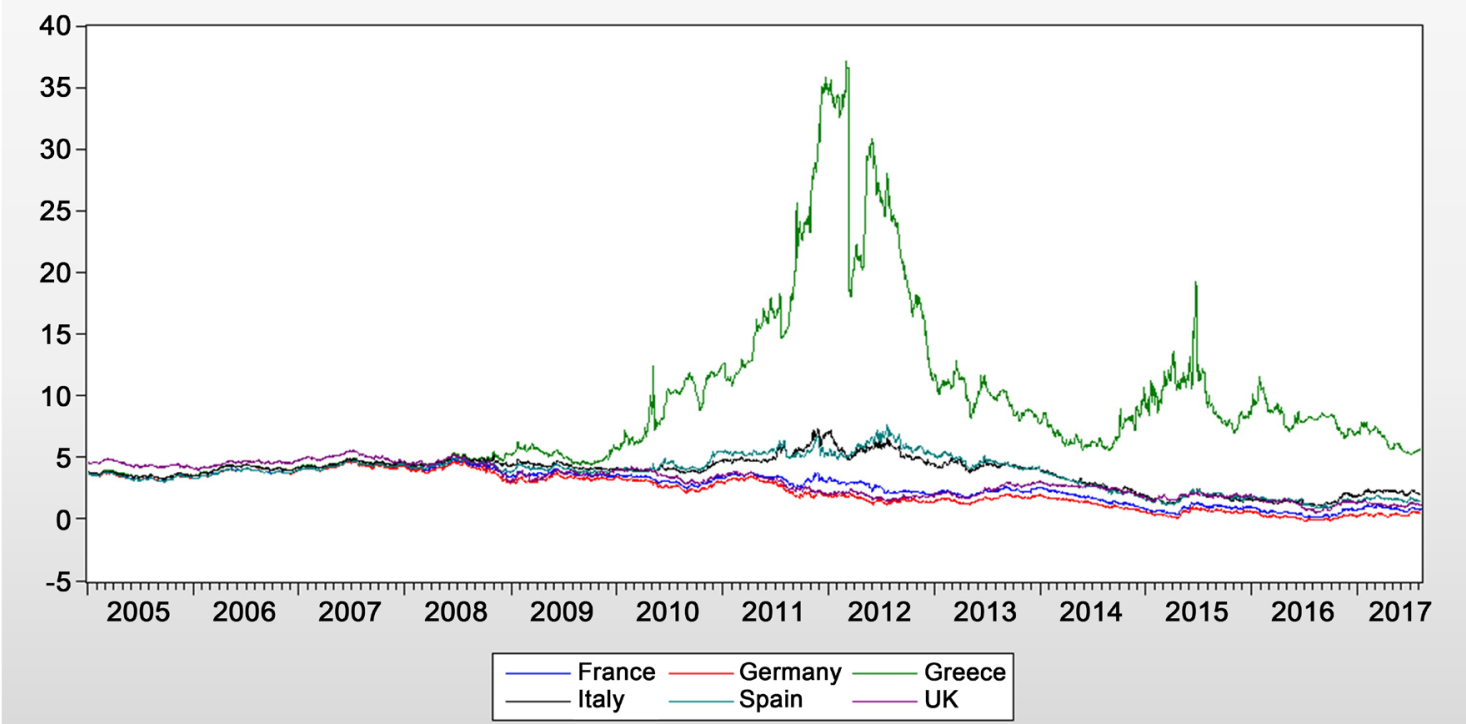

Source: Data taken from Bloomberg.

Figure 1. Daily yields for 10 years. 
The yield on the 10-year German bond index fell in negative territory for the first time ever, amid concerns about global growth and concerns about UK's exit referendum from the $\mathrm{EU}$, as investors continued to invest in safe assets. Bond and yield prices moved in opposite directions, what drove the return to negative direction?

Negative yields could be due to the emerging monetary policy with the stated objectives of stimulating economic growth as supply and pulp are not balanced on bonds. Negative interest rates on short-term deposits may, in conjunction with central bank purchases of fixed assets, lead to negative bond yields. The negative yields may predict a sharp economic slowdown, which could lead to deficits in both companies and governments in future. From the above figure, the large difference between yields of the German bonds and Greek bond yields are evident; there are many reasons for the existence of the gap between the two bonds. An attempt has been made to explain the factors affecting these bonds, as well as the relationship between these factors and bonds. Inflation is a key factor that has a significant impact on bond yields. For example, when the country faces rising inflation, bondholders will claim higher returns than the expected loss of purchasing power, which is likely to be high inflation, and free reinvestment at the time of higher inflation. Future bonds will not be traded at an interest rate equal to those that purchased initially.

\section{The Determinants of Sovereign Bond Yields}

Several researchers (Bernoth \& Erdogan, 2012; D’Agostino \& Ehrmann, 2014) have suggested that the evolution of sovereign bond spreads in the euro area countries is largely explained by a set of determinants of credit and liquidity risk and the degree of risk aversion. The relevance of these determinants is likely to vary over time. In particular, in times of financial uncertainty, the degree of risk aversion may increase, forcing investors to rebalance their portfolios by probably increasing their holdings of less risky securities. Sovereign bonds are also sensitive to credit and liquidity risks. This is a recurring finding in the empirical literature since the outbreak of last financial crisis. Many studies have examined the relationship between sovereign bond spreads and various macroeconomic indicators and variables. Gupta, Mati and Baldacci (2008), Eichengreen and Mody (1998) played an important role in explaining sovereign bonds. While Dell'Ariccia, Goedde and Zettelmeyer (2000); Ferrucci (2003); and Goldman Sachs (2000) extended these studies to identifying short and long-term determinants of sovereign bonds with a dynamic correction model. Ferrucci (2003) concludes that markets consider macroeconomic fundamentals when pricing sovereign risk.

Credit risk is generally associated with the probability of default of the government. Usually represented by variables that describe a country's fiscal position (debt and deficit-to-GDP ratios, debt structure, interest expenditure relative to GDP, etc. Given that investors may be more interested in assessing the fiscal 
outlook in order to assess a country's creditworthiness; many use fiscal fundamentals as explanatory variables in sovereign bond spreads. For example, D'Agostino and Ehrmann (2014) expand the range of variables used to capture credit risk against observed macroeconomic variables (current account balance-to-GDP ratio, real GDP growth, unemployment, and the consumption). While, De Santis (2012) argues that investors are taking into account fiscal developments to assess growth prospects and the government's ability to repay its debts. Studies like Eichler (2014), Di Cesare et al. (2012) and Klose and Weigert (2014) explicitly explored the role of budget variables in assessing the solvency of each country.

The liquidity of the various government bonds will most likely influence the yield spread. Bond liquidity is raising growing concern among the financial community: it has never regained its pre-crisis level, especially in riskier segments such as corporate bonds. Liquidity risk is often measured by use of difference between bid and ask prices which is lower for liquid assets (because there are more buyers and sellers, and therefore more movements), the depth of the market (the size of the country's debt), or even more complex variables, such as the spread with the German federal rate. The spread between sovereign and German bonds that can serve as a proxy for liquidity risk (since the guarantee is the same, the difference between the rates represents the liquidity spread). The credit spreads of vulnerable Eurozone countries have also been demonstrated to be a key determinant of the crash risk of the euro (Bekkour et al., 2015).

Finally, the investors' risk perception component helps explain some of the recent movements in bond yields. The idea is that in times of crisis, investors want to secure their investments and therefore retreats to the least risky assets. Conversely, unsecured sovereign bonds are abandoned, which increases spread. This has been the case for a few months with a strong demand on German bonds (followed by French bonds) compared to Italian or Spanish bonds. Risk aversion can be estimated by taking a variable such as the VIX (Chicago Board Exchange Market Volatility Index Options) or spread between AAA corporate bond rate and the US Treasury bond rate.

Modeling the precise effect of each component is a complex challenge. There are dozens of studies done for this purpose, with each of the different conclusions depending on econometric method, hypotheses, variables taken into account to estimate each component, the study period, and the choice of the sample.

\subsection{Data}

Our data sample includes 6 European countries: France, Germany, United Kingdom, Greece, Italy and Spain. The countries in the sample differ considerably in terms of the allocation of the interest rate paid on their 10-year government bonds relative to the benchmark index of German government bonds. For the included countries, the daily interest rates on 10-year benchmark bonds de- 
clared by the European Central Bank (ECB) for a period between January 1, 2005 and November 31, 2017 were obtained from Bloomberg.

The data for the base models are monthly values and since most of the data are published only in annual aggregates, linear interpolation is used to derive monthly values. The explanatory variables for the base models are: interest rate, inflation, debt to GDP, deficit to GDP, GDP growth rate and VSTOXX index. Linear interpolation is used to obtain monthly values of debt to GDP, deficit to GDP and GDP growth rate. To download these data, we used World Bank Open Data from the World Bank for each variable (the official website of the World Bank Open Data: https://data.worldbank.org/).

\subsection{Methodology}

Our econometric model uses a set of factors to explain the spread of national interest rates relative to the German benchmark. The choice of factors is guided by the theoretical considerations explained in the previous sections. We start with country estimates that show heterogeneity between the different countries in their estimated coefficients. Country average estimators are designed for macro-panels. The procedure consists of two steps:

- First, an estimate of a regression by country;

- Second, calculation of the average of the coefficients estimated by country.

For each country $i$, the regression equation is

$$
\begin{aligned}
Y_{i t}= & \beta_{i 0}+\beta_{i 1} X_{1 t}+\beta_{i 2} X_{2 t}+\beta_{i 3} X_{3 t}+\beta_{i 4} X_{4 t} \\
& +\beta_{i 5} X_{5 t}+\beta_{i 6} X_{6 t}+\beta_{i 7} Y_{t-1}+\varepsilon_{i t}
\end{aligned}
$$

where: $Y_{i t}$ is the bond spread of country $i, \beta_{i 0}$ is constant, $X_{1 t}$ is GDP growth rate variable, $X_{2 t}$ is VSTOXX -index variable, $X_{3 t}$ is Debt to GDP variable, $X_{4 t}$ is Deficit to GDP variable, $X_{5 t}$ is the ECB Interest Rate, $X_{6 t}$ is Inflation variable, $Y_{t-1}$ is lagged dependent variable and $\varepsilon_{i t}$ is error term.

Although we have added the lagged variable to the model, the Breusch-Godfrey test rejects the null hypothesis (no-autocorrelation) every time. The Newey-West (1994) standard errors with automatic lag-selection criteria for autocorrelation and heteroskedastic analysis were used.

After the manipulation of this first model, all the results are presented in Tables 3-8.

The 10-year government bond yield data for the six countries is in monthly averages and is collected from Bloomberg. Sovereign bond spread for each month is calculated by subtracting the monthly 10 -year government bond yield from corresponding Germany`s bond yield value.

\subsection{Results}

Results are presented in Tables 3-8. In the multiple regression situation, each coefficient $(\mathrm{Bi})$, estimated with model, represents the change in $\mathrm{Y}$ relative to a one unit change in independent variable $\mathrm{Xi}$. b1, holding all other independent variables constant. Average increase in the spread of sovereign bonds resulting 
Table 3. Determinants of spreads (estimations): Germany.

\begin{tabular}{cccc}
\hline Variable & Coefficient & t-Statistic & Prob \\
\hline C & -0.347736 & -1.255272 & 0.2115 \\
GDP \%** & -0.021372 & -2.218123 & 0.0282 \\
VSTOXX-index & $1.41 \mathrm{E}-07$ & 1.076469 & 0.2836 \\
Debt \% GDP & 0.006214 & 1.615820 & 0.1085 \\
Deficit \% GDP* & -0.024260 & -1.764912 & 0.0798 \\
Interest Rate*** & 0.129929 & 3.273557 & 0.0013 \\
Inflation & -0.013568 & -0.461333 & 0.6453 \\
SPREAD_1 & 0.880969 & 25.74568 & 0.0000 \\
Adjusted R-squared & 0.986450 & & \\
F-statistic & 1477.847 & & \\
Prob(F-statistic) & 0.000000 & &
\end{tabular}

Source: Estimations of parameters with Eviews.

Table 4. Determinants of spreads (estimations): France.

\begin{tabular}{|c|c|c|c|}
\hline Variable & Coefficient & t-Statistic & Prob. \\
\hline $\mathrm{C}$ & 0.009774 & 0.069656 & 0.9446 \\
\hline GDP \% & -0.013341 & -1.577202 & 0.1171 \\
\hline VSTOXX-index & $-1.17 \mathrm{E}-07$ & -1.497086 & 0.1367 \\
\hline Debt \% GDP & 0.000677 & 0.486624 & 0.6273 \\
\hline Deficit \% GDP & 0.00415 & 0.546169 & 0.5859 \\
\hline Interest Rate & -0.004886 & -0.268785 & 0.7885 \\
\hline Inflation & 0.009672 & 0.584874 & 0.5596 \\
\hline SPREAD_1 & 0.952462 & 24.17211 & 0 \\
\hline Adjusted R-squared & \multicolumn{2}{|c|}{0.924747} & \\
\hline F-statistic & \multicolumn{2}{|c|}{250.2817} & \\
\hline Prob(F-statistic) & \multicolumn{2}{|c|}{0} & \\
\hline
\end{tabular}

Source: Estimations of parameters with Eviews.

from unit percentage change in the variables indicated (except the constant $\mathrm{C}$ ). The impacts are statistically significant at $1 \%, 5 \%$ and $10 \%$, according to the classification ${ }^{* *},{ }^{* *}$ and ${ }^{*}$ respectively (value of the probability). If the regression coefficient is negative this means, for every unit increase in $\mathrm{Xi}, \mathrm{a}-\mathrm{b}$ value unit decrease in $\mathrm{Y}$ is expected, holding all other variables constant, as it is an inverse relationship. While, if the coefficient is positive, the relation is in the same direction. Therefore, any increase in $\mathrm{X}$ leads to an increase of $\mathrm{Y}$ and the same in the event of a fall.

For the German bonds yield, it is observed that coefficients of the GDP growth rate, Deficit to GDP ratio and inflation are negative. While those of 
Table 5. Determinants of spreads (estimations): UK.

\begin{tabular}{cccc}
\hline Variable & Coefficient & t-Statistic & Prob. \\
\hline C & 0.403369 & 3.313309 & 0.0012 \\
GDP \%*** & 0.038695 & 3.421908 & 0.0008 \\
VSTOXX-index*** & 0.004484 & 3.292362 & 0.0013 \\
Debt \% GDP*** & -0.012807 & -3.388906 & 0.0009 \\
Deficit \% GDP** & -0.032164 & -2.550496 & 0.0119 \\
Interest Rate & -0.042634 & -2.002730 & 0.0472 \\
Inflation & 0.012905 & 0.619714 & 0.5365 \\
SPREAD_1 & 0.893911 & 26.39179 & 0.0000 \\
Adjusted R-squared & & 0.930019 & \\
F-statistic & 270.5904 & \\
Prob(F-statistic) & 0.000000 &
\end{tabular}

Source: Estimations of parameters with Eviews.

Table 6. Determinants of spreads (2SLS estimations): Italy.

\begin{tabular}{cccc}
\hline Variable & Coefficient & t-Statistic & Prob. \\
\hline C & 0.062461 & 0.262000 & 0.7937 \\
GDP \%** & -0.010134 & -2.237220 & 0.0269 \\
VSTOXX-index & $-1.14 \mathrm{E}-07$ & -1.511189 & 0.1331 \\
Debt \% GDP & 0.000126 & 0.077385 & 0.9384 \\
Deficit \% GDP & 0.009556 & 0.836485 & 0.4044 \\
Interest Rate & -0.007392 & -0.433566 & 0.6653 \\
Inflation & 0.004725 & 0.315657 & 0.7528 \\
SPREAD_1 & 0.940268 & 24.24503 & 0.0000 \\
Adjusted R-squared & & 0.926161 & \\
F-statistic & 255.4437 & \\
Prob(F-statistic) & 0.000000 & \\
\hline
\end{tabular}

Source: Estimations of parameters with Eviews.

VSTOXX-index, Debt to GDP ratio and the interest rate are positive.

Results for the French bonds spread show that coefficients of the GDP growth rate, VSTOXX-index and interest rate are negative. While those of Deficit to GDP ratio, Debt to GDP ratio and inflation are positive. These results are not similar to the results of the German bonds, which justifies the disparities between these two countries.

Results for the British bonds spread show that coefficients of the GDP growth rate, VSTOXX-index and inflation are positive. While those of Deficit to GDP ratio, Debt to GDP ratio and interest rate are negative.

Results for the Italian bonds spread show that coefficients of the GDP growth 
Table 7. Determinants of spreads (2SLS estimations): Spain.

\begin{tabular}{cccc}
\hline Variable & Coefficient & t-Statistic & Prob. \\
\hline C & 0.017773 & 0.268672 & 0.7886 \\
GDP \% & -0.012464 & -1.655113 & 0.1002 \\
VSTOXX-index & $-7.87 \mathrm{E}-08$ & -1.007438 & 0.3155 \\
Debt \% GDP & 0.000688 & 1.187126 & 0.2373 \\
Deficit \% GDP & 0.002366 & 0.410968 & 0.6817 \\
Interest Rate & 0.005877 & 0.326343 & 0.7447 \\
Inflation & -0.004286 & -0.285493 & 0.7757 \\
SPREAD_1 & 0.921252 & 21.80586 & 0.0000 \\
Adjusted R-squared & & 0.926470 & \\
F-statistic & 256.5959 & \\
Prob(F-statistic) & 0.000000 &
\end{tabular}

Source: Estimations of parameters with Eviews.

Table 8. Determinants of spreads (2SLS estimations): Greece.

\begin{tabular}{cccc}
\hline Variable & Coefficient & t-Statistic & Prob. \\
\hline C & 0.090156 & 0.733507 & 0.4645 \\
GDP \%** & -0.015065 & -2.346550 & 0.0204 \\
VSTOXX-index & $-8.12 \mathrm{E}-08$ & -1.094887 & 0.2755 \\
Debt \% GDP & -0.000274 & -0.406271 & 0.6852 \\
Deficit \% GDP & -0.000305 & -0.100221 & 0.9203 \\
Interest Rate & 0.029700 & 1.478241 & 0.1417 \\
Inflation & -0.025905 & -1.438975 & 0.1525 \\
SPREAD_1 & 0.858109 & 16.35609 & 0.0000 \\
Adjusted R-squared & & & \\
F-statistic & & 0.927300 & \\
Prob(F-statistic) & & &
\end{tabular}

Source: Estimations of parameters with Eviews.

rate, VSTOXX-index and interest rate are negative. While those of Deficit to GDP ratio, Debt to GDP ratio and inflation are positive. These results are similar to the results of the French bonds, which justifies the similarities between these two countries.

For the Spanish bonds, coefficients of Deficit to GDP ratio, Debt to GDP ratio and inflation are positive while the coefficients for GDP growth rate, VSTOXX-index and interest rate are negative. These results are similar to the results of the French and Italian bonds.

Results for the Greek bonds spread show that all coefficients are negative, except interest rate. These results can be justified by the exceptional case in which 
Greece finds itself following the crisis of which it suffers.

\subsection{Discussion}

An attempt has been made to identify the reasons for evolution of dispersion of 10 -year bond yields between these countries of euro zone during the period 2005-2017 by the use of linear regression models to study the determinants of spread of the bonds. The analysis of results obtained in previous section shows that the fundamental factors (Debt-to-GDP ratio, GDP growth rate, Deficit to GDP ratio, interest rate, inflation and market sentiment) play an important role in the spreads observed for sovereign bond yields of the euro area. The results suggest that country-specific fundamentals have played an important role in evolution of bond spreads.

This corresponds to developments in euro area bond spreads before the crisis period, when countries with weak fiscal fundamentals such as Greece were able to borrow at rates close to those of Germany. To answer the question of whether accession to EU has affected the bond yields of these countries, one would conclude that during the crisis period bond yields were negatively affected by EU membership, but mainly because it could have benefited more to those who have increased risk aversion. The bond yields of Spain and Italy have risen during the crisis due to lack of lender of last resort.

However, low frequency data for fiscal fundamentals is a problem in the study. In addition, the UK bond spread was used to see if the special events affected the spread of these bonds differently. It seems that there has been a kind of convergence of bond yields in all countries which should partly explain the spread developments before the crisis.

This study allowed us to make a comparison of the countries and to note that the spread is highly variable between them. Subsequently, it has been demonstrated that this situation is a hindrance to the growth of the economies of the sub-region. The second part allowed us to explain the regression methodology, to estimate our models and to present the results. These results reveal that interest rate, Inflation, Debt to GDP, Deficit to GDP, Gross Domestic Product rate of growth, and VSTOXX index are the most significant determinants of the spread in the countries of the zone. Our results also state that in these countries, factors specific to the economic environment and the legal and institutional frameworks explain the intermediation margin better than the characteristics of the banks. For further work, the legal and institutional framework in each country could be taken into account to improve the quality of the results of this study.

\section{Conclusion}

To summarize, the main factors which affected bond spreads before the crisis, were not the country-specific fundamentals but rather the convergence of bond yields in the euro-zone countries due to and following the launch of the monetary union but during the crisis, increased risk aversion and lack of lender of last 
resort, shifted the focus to country specific factors and the bond spreads began to diverge according to the determinants highlighted in this study. Improvements in economic fundamentals have certainly helped in reducing sovereign bond spreads but remain insufficient as real GDP level in some euro area countries is still below their pre-financial crisis level and therefore QE shall continue to play a positive role in supporting and restoring the economic fundamentals of the euro area.

\section{References}

Acharya, V., Drechsler, I., \& Schnabl, P. (2014). A Pyrrhic Victory? Bank Bailouts and Sovereign Credit Risk. The Journal of Finance, 69, 2689-2739. https://doi.org/10.1111/jofi.12206

Beck, R., Georgiadis, G., \& Gräb, J. (2016). The Geography of the Great Rebalancing in Euro Area Bond Markets during the Sovereign Debt Crisis. Journal of Empirical Finance, 38, 449-460. https://doi.org/10.1016/j.jempfin.2016.01.003

Bekkour, L., Jin, X., Lehnert, T., Rasmouki, F., \& Wolff, C. (2015). Euro at Risk: The Impact of Member Countries' Credit Risk on the Stability of the Common Currency. Journal of Empirical Finance, 33, 67-83. https://doi.org/10.1016/j.jempfin.2015.06.004

Bernoth, K., \& Erdogan, B. (2012). Sovereign Bond Yield Spreads: A Time-Varying Coefficient Approach. Journal of International Money and Finance, 31, 639-656. https://doi.org/10.1016/j.jimonfin.2011.10.006

Blundell-Wignall, A. (2012). Solving the Financial and Sovereign Debt Crisis in Europe. OECD Journal: Financial Market Trends, 2011, 201-224. https://doi.org/10.1787/fmt-2011-5k9cswmzsdwj

D’Agostino, A., \& Ehrmann, M. (2014). The Pricing of G7 Sovereign Bond Spreads-The Times, They Are a-Changin. Journal of Banking \& Finance, 47, 155-176. https://doi.org/10.1016/j.jbankfin.2014.06.001

De Santis, R. (2012). The Euro Area Sovereign Debt Crisis: Safe Haven, Credit Rating Agencies and the Spread of the Fever from Greece, Ireland and Portugal.

Dell'Ariccia, M. G., Zettelmeyer, M. J., \& Schnabel, M. I. (2002). Moral Hazard and International Crisis Lending: A Test (No. 2-181). International Monetary Fund.

Di Cesare, A., Grande, G., Manna, M., \& Taboga, M. (2012). Recent Estimates of Sovereign Risk Premia for Euro-Area Countries.

Eichengreen, B., \& Mody, A. (1998). What Explains Changing Spreads on Emerging-Market Debt: Fundamentals or Market Sentiment? (No. w6408). National Bureau of Economic Research. https://doi.org/10.3386/w6408

Eichler, S. (2014). The Political Determinants of Sovereign Bond Yield Spreads. Journal of International Money and Finance, 46, 82-103. https://doi.org/10.1016/j.jimonfin.2014.04.003

Ferrucci, G. (2003). Empirical Determinants of Emerging Market Economies' Sovereign Bond Spreads.

Goldman Sachs (2000). A New Framework for Assessing Fair Value in Ems' Hard Currency Debt (Vol. 45). New York: Global Economics Paper.

Gupta, M. S., Mati, A., \& Baldacci, M. E. (2008). Is It (Still) Mostly Fiscal? Determinants of Sovereign Spreads in Emerging Markets (No. 8-259). International Monetary Fund. https://doi.org/10.5089/9781451871173.001

Klose, J., \& Weigert, B. (2014). Sovereign Yield Spreads during the Euro Crisis: Funda- 
mental Factors versus Redenomination Risk. International Finance, 17, 25-50. https://doi.org/10.1111/infi.12042

Praet, P. (2017). The ECB's Monetary Policy: Past and Present. https://www.ecb.europa.eu/press/key/date/2017/html/sp170316.en.html

Poghosyan, T. (2012). Long-Run and Short-Run Determinants of Sovereign Bond Yields in Advanced Economies. Economic Systems, 2012, 26.

https://doi.org/10.5089/9781475529142.001 